\title{
Multipl Sklerozda Metilprednizolonun Oksidatif Strese Etkisi
}

\section{Methylprednisolone Effect on Oxidative Stress in Multiple Sclerosis}

\author{
Fikri HALAÇOĞLU ${ }^{1}$, Ömer ANLAR ${ }^{2}$ \\ ${ }^{1}$ Çorum Özel Hastanesi, Nöroloji Bölümü, ÇORUM \\ ${ }^{2}$ Yıldırım Beyazıt Üniversitesi, Nöroloji Anabilim Dalı, ANKARA
}

\begin{abstract}
ÖZET
Bu çalışma 2009-2010 yılları arasında Ankara Atatürk Eğitim ve Araştırma Hastanesi 1. Nöroloji Kliniği Multipl Skleroz polikliniğinden takip edilen ve akut multipl skleroz atağ nedeniyle tedavi edilen 25 hasta ile yapıldı.

Akut atakta olan hastalara 7 gün boyunca yüksek doz metilprednizolon, 1000mg/gün, tedavisi uygulandi. Hastaların serumlarından tedavi öncesi ve tedavi sonrasında total antioksidan kapasite, total oksidan kapasite ve oksidatif stres endeksleri ölçüldü. Aynı zamanda hastaların tedavi öncesi ve tedavi sonrasında genişletilmiş özürlülük durum ölçeği karşılaştırıld1.

Multipl skleroz hastalarında tedavi sonrası serumlarında total antioksidan seviyenin tedavi öncesine göre anlamlı oranda artış gösterdiği $(\mathrm{p}<0.05)$, tedavi öncesi serum total oksidan kapasitenin tedavi sonrasına göre anlamlı oranda azaldığı gözlendi ( $\mathrm{p}<0.05)$. Buna bağlı olarak da tedavi öncesi serum oksidatif stres endeksinde tedavi sonrasına göre istatistiksel olarak anlamlı oranda azalma $(\mathrm{p}<0.05)$ ve tedavi sonras1 genişletilmiş özürlülük durum ölçeği ölçümlerinde tedavi öncesine göre anlamlı oranda azalma saptand1.

Yapmış olduğumuz bu çalışmanın sonuçlarına bakıldığında multipl skleroz atağında verilen yüksek doz metilprednizolon tedavisi, hem tedavi sonrasında oksidan kapasiteyi azaltarak hem de antioksidan kapasitenin artışını sağlayarak oksidatif stresi azaltma üzerinde etkisini göstermektedir.
\end{abstract}

ABSTRACT

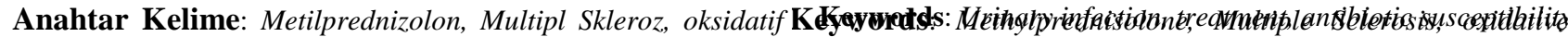




\section{GíRiş}

Multipl Skleroz (MS); santral sinir sisteminin (SSS) çeşitli bölgelerinde, kronik inflamasyon, demiyelinizasyon ve sklerozisle karakterize, ataklarla seyreden bir hastalıktır. Hastalık yaygın olarak, SSS miyelinine yönelir. MS, SSS beyaz cevherini etkileyen, gri cevher etkileniminin de olduğu bildirilen, etyolojisi tam olarak bilinmemekle beraber genetik ve çevresel faktörlerin rol aldığ1, otoimmün, inflamatuvar bir hastalıktır $(1,2)$. Kırk yaşın altında genç erişkinlerde en sık özürlülük yapan nörolojik hastalıktır (3).

MS kadınlarda daha sık görülür, kadın/erkek oranı 1,77/1'dir. Kadınlardaki ortalama başlangıç yaşı, erkeklerden 5 yıl daha öncedir (4). Belirtiler, en sık 20 ile 40 yaşları arasında başlamaktadır (5).

MS, beyaz 1rkta ve Avrupa kökenlilerde daha sık görülür (3).

MS' te genetik yatkınlık, otoimmün mekanizmalar, viral enfeksiyonlar, cinsiyet, çevresel faktörler demiyelinizasyon patogenezinde rol oynayabilir (6). Hastaların birinci derece akrabalarında MS görülme riski \%3-5, ikinci derece akrabalarında ise \%1,5-2,5' dir (7). Patolojik olarak, kısmen korunmuş aksonlarla birlikte beyaz maddede mültipl inflamasyon, demiyelinizasyon, oligodendrosit kaybı ve glial skleroz oluşumu ile karakterizedir $(8,9)$.

Yüksek doz intravenöz metilprednizolon (IVMP) tedavisi MS'in akut ataklarında standart olarak kullanılan tedavi yöntemidir. Bu tedavinin kan beyin bariyerinin permeabilitesini arttırdığ 1 ve magnetik rezonans görüntüleme (MRG) de kontrast tutulumunu baskıladığı gösterilmiştir. Tedavi 3-10 gün arasında değişmekle beraber genel uygulama 5-7 gündür. Tedavi süresi hastanın atak sırasındaki başvuru şikâyetleri, nörolojik muayenesi ve Genişletilmiş Özürlülük Durum Ölçeği skoruna (EDSS) göre değişmektedir. Hastaların tedaviye yanıtları nörolojik bulguların düzelmesi ve EDSS ile ölçülmektedir.
Serbest radikaller hücrelerin lipid, protein, DNA (deoksiribonükleik asit), karbonhidrat ve enzim gibi bileşiklerini etkilerler (10,11). Serbest oksijen radikallerinin nükleik asitler ve DNA'ya etkisi ile DNA zincirinde kopmalar bazlarda ve deoksiribozlarda kırılmalar oluşur (12).

Antioksidanlar, hedef moleküllerdeki oksidatif hasarı engelleyen veya geciktiren maddelerdir. Antioksidanlar genel olarak endojen ve ekżojen antioksidanlar olmak üzere iki grupta incelenir (13). Enzimatik antioksidanlar: mitokondrial sitokrom oksidaz sistemi, süperoksit dismutaz, katalaz, glutatyon peroksidaz, glutatyon S transferaz, glutatyon redüktazdır. Enzimatik olmayan antioksidanlar: vitamin E, karoten, retinoidler, vitamin $\mathrm{C}$, melatonin, sistein, seruloplazmin, transferin, laktoferrin, miyoglobin, albümin, bilürubin, glutatyondur (12). Ürik asit, sistin, albumin, bilürubin, seruloplazmin, transferrin, laktoferrin, ferritin, kreatinin ve östrojenler de serbest radikallere karşı koruyucu rol oynarlar (14). Ekzojen antioksidanlar: A, C, E vitamini ve beta karoten, bütile hidroksitoluen, bütile hidroksianisol, sodyum benzoat, etoksikuin, puropil galate, demir süperoksit dismutazdır. Normal koşullarda organizma serbest radikaller ve bunlara bağlı gelişen oksidatif stres ile mücadele eden antioksidan sistemine sahiptir (15).

Total antioksidan kapasite (TAOK) ye en büyük katk1 antioksidan moleküllerden gelmektedir. Sağlıklı bireylerde TAOK'nin \%49'unu proteinlerin, \%5'ini vitamin C'nin, \%1,7'sini bilurubinlerin oluşturduğu bilinmektedir (16). Plazma ve vücut sıvilarında bulunan antioksidanların toplam etkisini TAOK yansıtır. Kanın antioksidan durumunu saptamada bireysel antioksidanlardan ziyade bunların toplam antioksidan değerini veren TAOK ölçümü yaygınlaşmaktadır (17). Oksidatif stres endeksi (OSE): Total oksidan seviye (TOS)'nin, TAOK'a bölünmesiyle elde edilen oransal bir indekstir. Yüksek bulunduğu durumlar oksidatif stresin arttığını göstermektedir (18). 
Son yıllarda yapılan çalışmalar, MS'in etyopatogenezinde oksidatif stres ile inflamasyonun birlikte rol aldığını göstermektedir. $\mathrm{Bu}$ doğrultuda planladığımız çalışmamızda amacımız, RelapsingRemitting Mültipl Skleroz (RRMS), RelapsingProgressif Mültipl Skleroz (RPMS) ve Sekonder Progressif Mültipl Skleroz (SSPMS) hastalarının akut atakta ve 7. günde $1000 \mathrm{mg}$ /gün metilprednizolon tedavisi sonrasında serumlarında TOS, TAS (Total antioksidan seviye) ve OSE değerlerinde olası değişikliklerin araştırılmasıdır.

\section{GEREÇ VE YÖNTEM}

Bu çalışmaya Haziran 2009 ile Ocak 2010 tarihleri arasında Ankara Atatürk Eğitim ve Araştırma Hastanesi 1.Nöroloji Kliniğine başvuran McDonald 2005 revize tanı kriterlerine göre MS tanısı almış ve MS atak ile başvuran hastalar alındı. Çalışma kontrollü, prospektif olarak planlandı ve Ankara Atatürk Eğitim ve Araştırma Hastanesi Etik Kurulunun onayı alındı.

Akciğer hastalığı, hipoksi-anoksi, doğumsal kromozom anomalisi, metabolik hastalık, polisitemi, veya enfeksiyon gibi serbest radikal oluşumuna neden olabilecek hastalı bulguları saptanan hastalar çalışmaya alınmadı.

Bu çalışmada 25 MS hastasına 7 gün boyunca yüksek doz IVMP (intravenöz metilprednizolon) tedavisi verildi. Tedavi öncesi ve sonrası serum TAS, TOS, OSE değerleri karşılaştırıldı.

TAOK, Erel yöntemi ile ölçüldü. $\mathrm{Bu}$ ölçüm yönteminde 2,2' - azinobis - (3-ethylbenzothiazoline-6sulfonic acid) (ABTS) radikali kullanılmaktadır. ABTS radikali, antioksidan konsantrasyonuna ve antioksidan kapasiteye göre mavi ve yeşil rengini kaybetmektedir. $\mathrm{Bu}$ renk değişikliği, absorbans değeri 660 nm'de ölçülerek değerlendirme yapılmaktadır. $\mathrm{Bu}$ ölçüm metodunun prensibi hidrojen peroksit varlığında ABTS molekülünün $\mathrm{ABTS}^{+}$molekülüne okside olmasına dayanmaktadır. $30 \mathrm{mmol} / \mathrm{L}$ asetat tamponu ve $\mathrm{pH}$ : 3,6'da koyu yeşil renkte olan radikalin, asetat tamponu 0,4 mol/L, pH: 5,8 olduğunda rengi açılmaktadır. Renk değişimi ile örnek içindeki antioksidan miktarı arasında ters ilişki bulunmaktadır. Reaksiyon hızı standart yöntem olan Trolox ile kalibre edilmektedir. Birimi Trolox equivalent/L.

TOS / TAOK şeklinde bölünerek OSE hesaplandı $(145,146)$

İstatistiksel analiz için SPSS 16,0 paket programı kullanıldı. Değişkenlerin normal dağılıma uygunluğu Kolmogorov Smirnov testi ile değerlendirildi. Grup karşılaştırmalarında Mann Whitney Testi ve Paired Ttesti kullanıldı ve $\mathrm{p} \leq 0.05$ değeri istatistiksel olarak anlamlı kabul edildi.

\section{BULGULAR}

İncelenen 25 hastanın 14'ü ( \%56) kadın, 11'i ( \%44) erkek olup yaş ortalamaları 36,6 $\pm 11,5$ idi, yaş dağılımı 21-68 arasında değişmekteydi. Kadın olguların yaş ortalaması $36,4 \pm 3,6$, erkek olguların yaş ortalaması ise $36,8 \pm 2,8$ idi. Olguların 20'si (\%80) RRMS, 3'ü (\%12) RPMS, 2'si (\%8) SPMS tipindeydi. Olguların 18'i (\%72) immünmodulatör tedavi, 7'si (\%28) immünsüpresif tedavi alıyordu. Tedavi süresi 0,4- 15 yıl arasında değişmekteydi. Tedavi öncesi TAS değerleri ile tedavi sonrası TAS değerlerinin karşılaştırıldığında istatistiksel olarak anlamlı farklılık saptand1 ( $p=0.005$, Paired T-Testi). Tedavi öncesi TOS değerleri ile tedavi sonrası TOS değerlerinin karşılaştırıldığında istatistiksel olarak anlamlı farklılık saptand 1 ( $p=0.008$, Paired T-Testi). Tedavi öncesi OSE ile tedavi sonrası OSE karşılaştırıldığında istatistiksel olarak anlamlı farklılık saptand $1(p=0.002$, Paired $T$ Testi). Tedavi öncesi EDSS ile tedavi sonrası EDSS karşılaştırıldığında istatistiksel olarak anlamlı farklılık saptand1. ( $p=0.001$, Paired T-Testi) 


\section{TARTIŞMA}

MS, genç yaşta ortaya çıkması, özürlülük oluşturması ve kronik bir hastalık olması nedeni ile yaşam kalitesini en çok etkileyen hastalıklardan birisidir. MS'de SSS'de en s1k görülen patoloji miyelin hasarıdır. Oligodendrositler ve miyelin kılıf oksidatif hasara karşı hassastır. Miyelin yıkılımı başladığında miyelin kılıfta yoğun olarak bulunan demir iyonları açığa çıkar ve hidroksil radikali oluşumu için gerekli öncü maddeler sağlanmış olur. Miyelin lipidleri hidroksil radikaline karşı dayanıksızdır ve çeşitli lipid peroksidasyon ürünleri açığa çıkar (19).

Serbest radikallerin zararlı etkileri sınırlamak için organizmada güçlü bir antioksidan sisteme ihtiyaç vardır. Oksidan ve antioksidan sistemler arasındaki dengesizlik oksidatif stres durumuna ve bu da bazı hastalıklara (Parkinson, mültipl skleroz, kanser vs.) yol açabilir (20). Dokularda ve makro moleküllerde gelişen oksidatif hasarı önlemek amacıyla bütün canlı organizmalarda kompleks özellikleri olan enzimatik ve non enzimatik antioksidan sistemler geliştirilmiştir (21)

Syburra C ve ark. oksidatif zarar santral sinir sisteminde demir salınımını serbestleştirerek hücrelerde hasar meydana getirdiğini belirtmektedirler (22).

İnflamasyonda artan serbest radikallerin etkisiyle oluşan oksidatif hasarın en önemli belirtisi lipid peroksidasyonudur. Lipid peroksidasyon ürünlerinin düzeyleri nötrofil aracılı inflamatuvar hasarın şiddetini yansitir (23).

MS patolojisi içerisinde yer alan inflamasyon sırasında makrofajların oksidatif patlamalarıyla yüksek konsantrasyonda ROR (reaktif oksijen radikalleri) salınır. $\mathrm{Bu}$ da hücresel savunma mekanizmalarının devre dışı kalmasına ve protein, lipid ve nükleik asitlerde oksidatif hasara neden olur. Oksidatif stres belirteçleri MS hastalarının serum ve BOS'larında yüksek oranda bulunmuştur. Ayrıca MS hastalarının lökositlerinde ROR üretiminin sağlıklı bireylerden yüksek oluşu oksidatif stresin MS patogenezindeki rolünü desteklemektedir ( 23).

Kortikosteroidler, $\mathrm{T}$ hücre fonksiyonlarını modüle ederek, makrofajlar üzerinde sınıf II antijen ekspresyonunu azaltarak, proenflamatuvar sitokinlerin yapımını ve aktivitesini inhibe ederek, interlökin (IL-1, IL-2, IL-6) yapımını azaltırlar ve birlikteliğinde ROR salınımını dolaylı yoldan azaltırlar. Kortikosteroidler MS akut alevlenmesinde s1klıkla kullanılmaktadır. Kortikosteroidlerin makrofajlar üzerinde bulunan antijenik maddelerin interlökin salgılanmasını bask1layarak oksidan kapasitesinin azalmasına katk1 sağladığı düşünülmektedir. Kortikosteroidlerin MS'de ilk görülen etkisi kan beyin bariyeri bozulmasını önlemektir. Kan beyin bariyeri restorasyonu, steroid hormonların direkt ve hızlı membran etkileri ile oluşur. Bununla birlikte hala bu ilaçların etkinliği, ilaç tipi, optimal dozu, tedavi süresi, sıklığı, verilme şekli net değildir. Yüksek doz IVMP'nin MS'de faydalı etkileri uzun zamandır bilinmektedir. Henüz hızlı yararlı etkinin nasıl olduğu açıklanamamıştır (24).

Çalışmamızda TAS MS hastalarının tedavi öncesi grubunda, tedavi sonrası gruba göre anlamlı derecede düşük saptandı $(p<0.05)$. Aynı zamanda MS atağı olan MS hastalarında TOS tedavi öncesi grup da tedavi sonrası gruba göre anlamlı oranda yüksek saptandı $(p<0.05)$. Kadın ve erkeklerdek yüksek doz IVMP tedavi sonrasında TAS ve TOS, OSE arasında anlamlı fark gözlenmemiştir.

LeVine SM ve ark. yapmış olduğu bir çalışmada MS hastalarında serbest radikal aktivitede artış ve antioksidan enzim sisteminde defekt olduğu sağlıklı kontrol grubu ile karşılaştırıldığında gözlenmiştir (19).

Buradan şu sonuç çıkarılabilir: TAS'ın steroid tedavisi ile artarak MS hastalarının patofizyolojisinde yer alan kan beyin bariyer bozukluğunun önlenmesinde etkisi olabileceği belirtilmiştir (25). Kortikosteroidlerin MS'de patofizyolojiye etkileri yönünde ortaya atılmış olan birçok çalışma mevcuttur. Ancak oksidan 
maddelerin puls steroid tedavi sonrası azalması ve puls steroid tedavi sonrası antioksidan kapasitenin artması yönünde yapılmış çalışmalar çok sınırlıdır.

Total antioksidan durumun ölçümü, antioksidanların tek tek ölçümünden daha değerli bilgiler verebilir. Plazma ve vücut sıvilarında bulunan bütün antioksidanların toplam etkisini TAOK yansitır. $\mathrm{Bu}$ yüzden kanın antioksidan durumunu saptamada bireysel antioksidanlardan ziyade bunların toplam antioksidan değerini veren TAOK ölçümü yaygınlaşmaktadır (26).

Çalışmamızda MS'te atak öncesi dönemde TOS' un tedavi sonrası düzeylerine göre anlamlı olarak yüksek gözlenmesi lipid peroksidasyonunun ve oksidatif stresin arttığını göstermektedir. Tedavi sonrası grupta TOS 'un tedavi öncesi gruba göre düşük bulunması metilprednizolon tedavisinin oksidatif stresi azaltmak yönünde etkili olduğunu göstermektedir.

Bizim çalışmamızda akut MS atağı geçiren hastalarda puls steroid tedavi verildi, tedavi öncesi ve tedavi sonrası TAS, TOS ve OSE bakıldı. Tüm bu parametrelerde tedavi öncesi ve tedavi sonras1 istatistiksel olarak değerlendirmelerde anlamlı farklılık gözlendi.

$\mathrm{Bu}$ çalışmanın sonucunda yüksek doz MP tedavisinin bilinen hipotezlerinden olan inflamatuvar sitokin kaskadını kırdığı, T hücre aktivasyonunu baskıladığı, immün hücrelerin SSS geçişini yavaşlattı̆̆ı, aktive olmuş immün hücrelerin apopitozunu kolaylaştırdığı, NO ve TNF- $\alpha$ 'nın sitotoksik etkilerini azaltarak atak esnasındaki demiyelinizasyon hasarı üzerindeki etkileri yanında yüksek doz MP tedavisinin oksidatif stresi ve TOS ve TAS üzerine etkilerine bakılarak MS atak tedavisinde uzun yıllardır kullanılan yüksek doz MP tedavisi hakkından farklı bir etki mekanizması araştırılmıştır.

\section{KAYNAKLAR}

1. Rizzo JF, Lessel S. Risk of developing multiple sclerosis after uncomplicated optic neuritis, A long term prospective study, Neurorology. 1988; 185-90.

2. Eraksoy M, Akman Demir G. Merkezi sinir sisteminin miyelin hastalıkları. Öge AE, editörler. Nöroloji. İstanbul: Nobel Tip Kitabevleri, 2004: 505-34.

3. W. Ian McDonald, John H. Noseworthy. Multiple Sclerosis 2. In: Roland Martin, Claudia F. Lucchinetti, W. Brück, (eds). Immunology, Pathology and Pathogenesis (First ed.) ButterworthHeinemann, Philadelphia 2003, p. 33-113.

4. Oğul E. Klinik Nöroloji. Nobel \& Güneş, Bursa 2002.

5. Gironi M, Bergami A, Brambilla E, et al. Immunological markers in multiple sclerosis. Neurol Sci. 2000; 21: 871-5.

6. Gilroy J. Basic Neurology Çeviri ed: Rana Karabudak. 3.baskı, Ankara: Güneş Yayınevi, 2002; 199-219.

7. Sav A. Multipl Skleroz'un Patolojik Bulguları. Türkiye Klinikleri Nöroloji Multipl Skleroz (Özel Say1). 2004; 2(3): 177-82.

8. Aeron E Miller, Fred D Lublin, Patricia K Coyle. Multiple Sclerosis in Clinical Practice (First ed) Taylor \& Francis Group, London 2003, p. 1-29, 103-29.

9. Hickey WF. The pathology of multiple sclerosis: a historical perspective. J Neuroimmunol. 1999; 98: $37-44$.

10. Kılınç K, Kılınç A. Oksijen toksisitesinin aracı molekülleri olarak oksijen radikalleri. Hacettepe Tıp Dergisi. 2002; 33: 110-118.

11. Jacop RA, Burr BJ. Oxidative damage and defense. Am J Clin Nutr. 1996; 63: 985-990.

12. Akkuş İ. Serbest radikaller ve fizyopatolojik etkileri. Konya: Mimoza Yayınları, 1995: 3-95. 
13. Yalçın AS. Antioksidanlar. Klinik Gelişim. 1998; 11: 342-46.

14. Reiter R, Tang L, Garcia JJ, Munoz-Hoyos A. Pharmacological actions of melatonin in oxygen radical pathophysiology. Life Sci. 1997; 60: 225571.

15. Yao JK, Reddy R, McElhinny LG, van Kamen DP. Reduced status of plasma total antioxidant capacity in schizophrenia. Schizophr Res. 1998; 32: 1-8.

16. Ghiselli A, Serafini M, Natella F, Scaccini C. Total antioxidant capacity as a tool to assess redox status: critical view and experimental data. Free Radic Biol Med. 2000; 29: 1106-14.

17. Erel O. A novel automated method to measure total antioxidant response against potent free radical reactions. Clin Biochem. 2004; 37: 112-19.

18. Harma M, Erel O. Oxidative stress in women with preeclampsia. Am J Obstet Gynecol. 2005; 192: 656-57.

19. LeVine SM. The role of reactive oxygen species in the pathogenesis of multiple sclerosis. Med Hypotheses. 1992; 39: 271-74.

20. Julien Finaud, G'erard Lac, Edith Filaire. Oxidative stres relationship with exercise and training. Sports Med. 2006; 36: 327-58.
21. Robles R, Palominoa N, Robles A: Oxidative stress in the neonate. Early Human Development (Suppl) 2001; 65: 75-81.

22. Syburra C, Passi Oxidative stress in patients with multiple sclerosis. Ukr Biokhim Zh. 1999; 71: 112115.

23. Masotti L, Casali E, Gesmundo N et al. Lipid peroxidation in cancer cells. Chemical and physical studies. Annals of New York Academy of Sciences. 1998; 551: 47-57.

24. Filippini G, Brusaferri F, Sibley WA, Citterio A, Ciucci G, Midgard R, Candelise L. Corticosteroids or ACTH for acute exacerbations in multiple sclerosis. Cochrane database of systematic reviews 2007.

25. Filipović SR, Drulović J, Stojsavljević N, Lević Z. The Effects of high-dose intravenous methylprednisolone on event-related potentials in patients with multiple sclerosis. J Neurol Sci. 1997; 152(2): 147-53.

26. Ghiselli A, Serafini M, Natella F, Scaccini C. Total antioxidant capacity as a tool to assess redox status: critical view and experimental data. Free Radic Biol Med. 2000; 29: 1106-14. 